\title{
Alopecia Areata Developing in Non-Insulin Dependent Diabetes Mellitus Type-2, an Autoimmune Disease
}

\author{
Virendra N Sehgal* \\ Dermato-Venereology (Skin/VD) Center, Sehgal Nursing Home, India
}

Submission: November 17, 2018; Published: January 25, 2019

*Corresponding author: Virendra N Sehgal, Dermato Venerology (Skin/VD) Centre Sehgal Nursing Home,A/6 Panchwati, Delhi-110 033, India

Keywords: Non-insulin diabetes mellitus; Diagnosed; Polydipsia; Polyphazia; Polyuria; Glycosylated hemoglobin; Alopecia areata; Pancreatic endocrine; Overlapping syndrome

Abbreviations: NIDDM: Non-Insulin Diabetes Mellitus; OLAS: Overlap Autoimmune Syndrome; MAS: Multiple Autoimmune Syndrome; HB: Hemoglobin Test

\section{Introduction}

A 53-years-old elegant woman weighing $65 \mathrm{Kg}$, a wellestablished incumbent of non-insulin diabetes mellitus (NIDDM) type 2 was diagnosed on the basis of polydipsia, polyphazia and polyuria with apparent time to time fluctuating blood sugar level determine by glucometer the fasting blood sugar as well as post prandial blood sugar has been invariably high. Pancreatic endocrine test the glycosylated hemoglobin test (HbA1c) 8.5\%. Accordingly, oral anti-diabetic treatment comprising metformin 500 milligram, glimepride 2 milligram, and pioglitazone 15 milligram is being administered ever since an hour before major meals. She has been by enlarge comfortable following therapy. However, she was taken aback by an asymptomatic wellcircumscribed local loss of hair, the alopecia areata [1] confined to the temporal aspect of the scalp (Figure 1), that brought the patient for expert opinion.

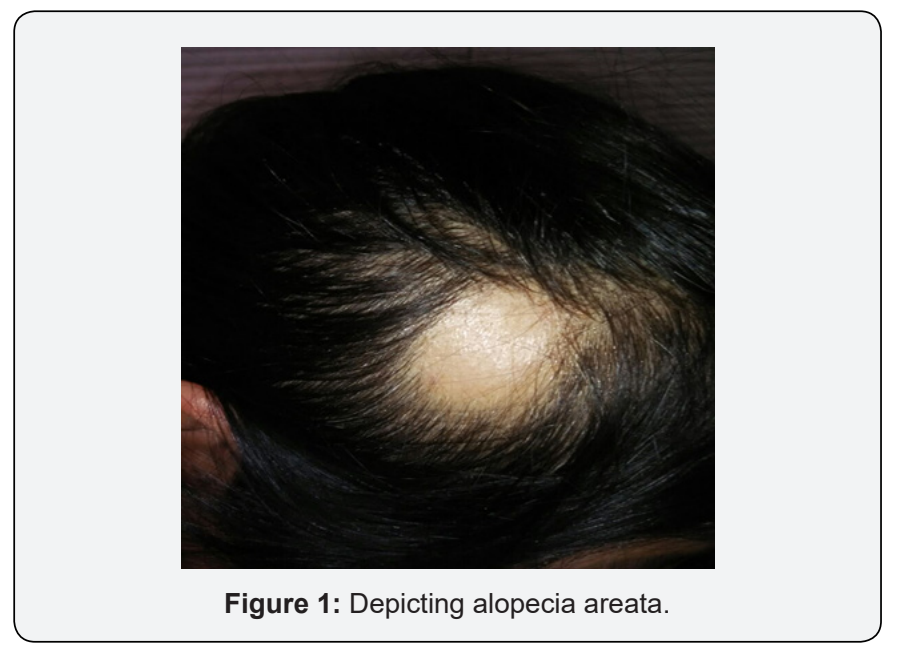

Table 1: Endocrine Glands Function Test.

\begin{tabular}{|c|c|c|c|}
\hline Endocrine Glands & Endocrine Function Test & Value & Normal Value \\
\hline HbA1c & Glycosylated hemoglobin Test & $8.50 \%$ & $5.7 \%-6.4 \%$ \\
\hline Adrenal glands & Adrenal function test (ACTH) & $29.30 \mathrm{pg} / \mathrm{mL}^{*}$ & $<46.00$ \\
\hline \multirow{3}{*}{ Thyroid glands } & T3 & $2.49 \mathrm{pg} / \mathrm{mL}$ & $2.30-4.20$ \\
\hline & $\mathrm{T} 4$ & $1.22 \mathrm{ng} / \mathrm{dL}$ & $0.89-1.76$ \\
\hline & $\mathrm{TSH}$ & $4.561 \mathrm{uIU} / \mathrm{mL}$ & $0.550-4.780$ \\
\hline Parathyroid glands & Parathyroid hormone (PTH) & $35.50 \mathrm{pg} / \mathrm{mL}$ & $14.00-72.00$ \\
\hline Prostate gland & Prostate specific antigen (PSA) & $0.505 \mathrm{ng} / \mathrm{mL}$ & $<4.00$ \\
\hline \multirow{3}{*}{ Female Gonads } & Ovarian function test & $465.27 \mathrm{ng} / \mathrm{dL}$ & $241.00-827.00$ \\
\hline & \multirow{2}{*}{ Follicle stimulating hormone (FSH) } & \multirow{2}{*}{$58.76 \mathrm{mIU} / \mathrm{mL}$} & Adult female \\
\hline & & & Follicular 2.50-10.20 \\
\hline
\end{tabular}




\section{Current Research in Diabetes \& Obesity Journal}

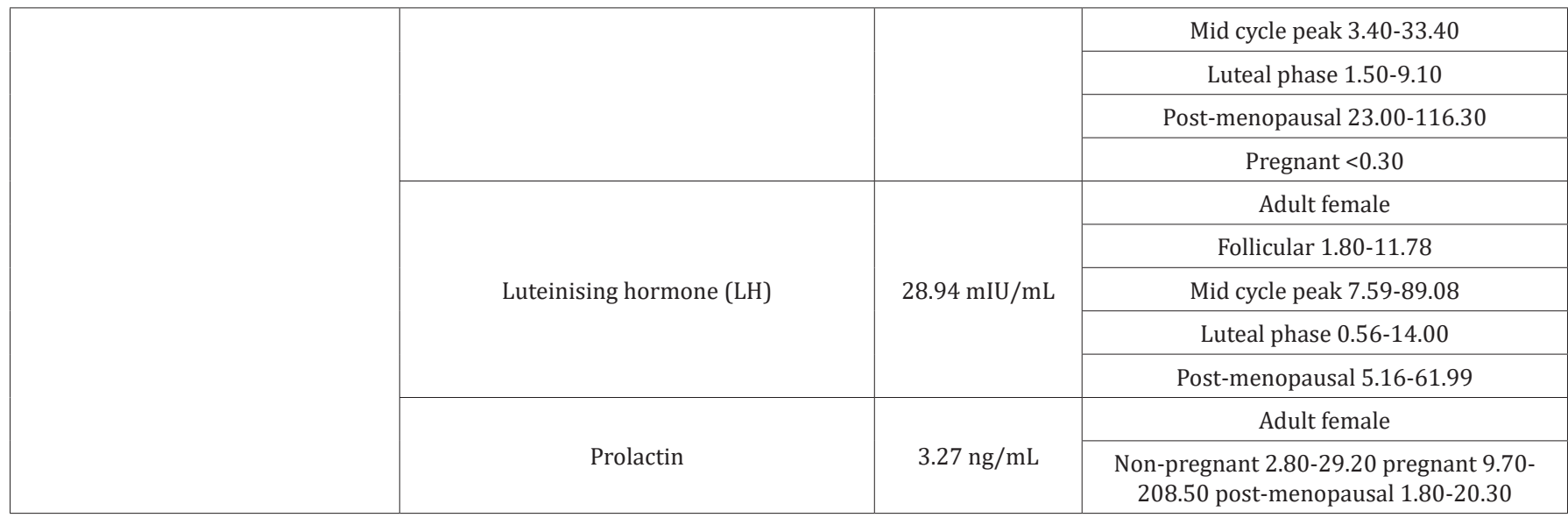

${ }^{*}$ picograms per millilitre $(\mathrm{pg} / \mathrm{mL})$

All the endrocrine functions test were within normal range, except for pancreatic function test, the glycosylated hemoglobin test $(\mathrm{HbA1c})$ was high. The endocrine function test including thyroid gland, parathyroid gland, adrenal cortex, pancreas and ovaries the female gonad was requisition to take stock of autoimmunity (Table 1), the multiple autoimmune syndrome (MAS) [2] / overlap autoimmune syndrome (OLAS)

Non-insulin dependent diabetes mellitus (NIDDM) type 2, a well-known autoimmune disease, of diverse undertone [3] / adult onset diabetes mellitus [4]. Indeed, alopecia areata developing in NIDDM type 2 is intriguing, reiterating autoimmunity as its probable etiology [5], a glaring illustration of multiple / overlapping syndrome, the reporting of such cases is too few and far between [6]. Surely, reporting of these cases should prove informative for the future.

\section{References}

1. Sehgal VN, Jain S (2003) Alopecia areata: clinical perspective and an insight into pathogenesis. J Dermatol 30(4): 271-289.

2. M Cojocaru, Inimioara Mihaela Cojocaru, Isabela Silosi (2010) Multiple autoimmune syndrome. Maedica (Buchar) 5(2): 132-134.

3. Velloso LA, Eizirik DL, Cnop M (2013) Type 2 diabetes mellitus--an autoimmune disease? Nat Rev Endocrinol 9(12): 750-755.

4. WHO (2013) Diabetes Fact sheet $N^{\circ} 312$ ". WHO, Geneva, Switzerland.

5. Saylam Kurtipek G, Cihan FG, Erayman Demirbaş Ş, Ataseven A (2015) The Frequency of Autoimmune Thyroid Disease in Alopecia Areata and Vitiligo Patients. Biomed Res Int 2015: 435947.

6. Wang SJ, Shohat T, Vadheim C, Shellow W, Edwards J, et al. (1994) Increased risk for type I (insulin-dependent) diabetes in relatives of patients with alopecia areata (AA). Am J Med Genet 51(3): 234-239.

Your next submission with Juniper Publishers
will reach you the below assets
- Quality Editorial service
- Swift Peer Review
- Reprints availability
- E-prints Service
- Manuscript Podcast for convenient understanding
- Global attainment for your research
- Manuscript accessibility in different formats
( Pdf, E-pub, Full Text, Audio)
- Unceasing customer service
Track the below URL for one-step submission
https://juniperpublishers.com/online-submission.php

